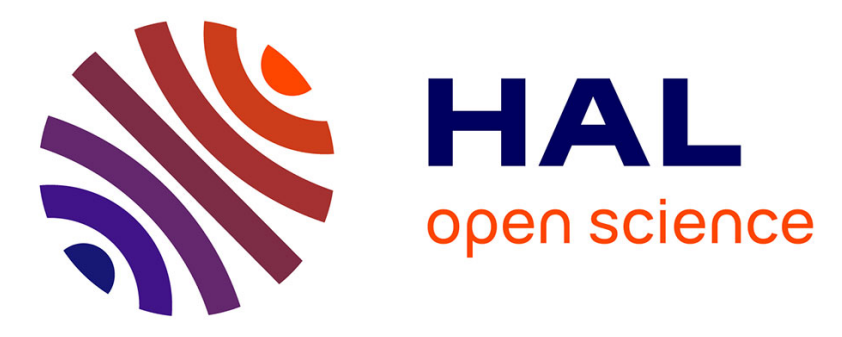

\title{
From SCM to Eco-Industrial Park Management: Modelling Eco-Industrial Park's Symbiosis with the SCOR Model
}

\author{
Mathilde Le Tellier, Lamia Berrah, Benoit Stutz, Simon Barnabé, \\ Jean-François Audy
}

\section{To cite this version:}

Mathilde Le Tellier, Lamia Berrah, Benoit Stutz, Simon Barnabé, Jean-François Audy. From SCM to Eco-Industrial Park Management: Modelling Eco-Industrial Park's Symbiosis with the SCOR Model. IFIP International Conference on Advances in Production Management Systems (APMS), Sep 2017, Hamburg, Germany. pp.467-478. hal-01707290

\author{
HAL Id: hal-01707290 \\ https://hal.inria.fr/hal-01707290
}

Submitted on 12 Feb 2018

HAL is a multi-disciplinary open access archive for the deposit and dissemination of scientific research documents, whether they are published or not. The documents may come from teaching and research institutions in France or abroad, or from public or private research centers.
L'archive ouverte pluridisciplinaire HAL, est destinée au dépôt et à la diffusion de documents scientifiques de niveau recherche, publiés ou non, émanant des établissements d'enseignement et de recherche français ou étrangers, des laboratoires publics ou privés. 


\title{
From SCM to Eco-Industrial Park management : Modelling Eco-Industrial Park's symbiosis with the SCOR model
}

\author{
Mathilde Le Tellier ${ }^{1,2,3}$, Lamia Berrah ${ }^{2}$, Benoit Stutz $^{1}$, Simon Barnabé ${ }^{3}$, and Jean-François \\ Audy $^{3}$ \\ 1 Univ. Savoie Mont Blanc, CNRS, LOCIE, F-73000 Chambéry, France benoit.stutz@univ-smb.fr \\ 2 Univ. Savoie Mont Blanc, LISTIC, F-74000 Annecy, France \\ (mathilde.le-tellier; lamia.berrah)@univ-smb.fr \\ 3 Univ. du Québec à Trois-Rivières, Trois-Rivières, Canada \\ (jean-francois . audy; simon. barnabe) @uqtr.ca
}

\begin{abstract}
From a business perspective, initiatives are undertaken at both inter-company level and intra-company level to implement the concept of sustainable development. At intercompany level, Industrial Ecology uses natural ecosystems as analogies to design sustainable industrial systems such as Eco-Industrial Parks (EIPs). Similarly to a Supply Chain (SC), an EIP is a community of independent businesses that cooperate with each other to efficiently share resources (materials, resources and information). However, if the SC cooperation is focused on product manufacturing, the EIP cooperation intends to reap economic gains, improvements in environmental quality and equitable enhancement of human resources that would not have been achievable individually. In the extensive and multidisciplinary body of literature studying EIP, the lack of a framework to evaluate the performance and benefits of an EIP is repeatedly discussed. Having observed similarities between SCs and EIPs, the use of Supply Chain Management tools for the description of synergies among an EIP is motivated. A model inherited from SCOR model is proposed to map this symbiosis and is demonstrated in a case study. Even if EIPs and SCs do not share the same goals, we will conclude with the relevance of using the SCOR model for EIP management.
\end{abstract}

Keywords: Supply Chain Management, Eco-Industrial Park, SCOR model, Industrial Ecology, Industrial Symbiosis

\section{Introduction}

With the growing presence of environment and energy security concerns, it has become clear that human activities and business activities in particular are having a preoccupying negative impact on our planet. Rising population sizes and increasing urbanisation call for an efficient use of resources embodied by the concept of sustainability as introduced in the Brundtland Report, by the United Nations World Commission on Environment and Development in 1987 [28]. From a business perspective, initiatives dealing with sustainability are initiated at both inter-company level and intra-company level, those initiatives are regrouped within the spectrum of 'Eco-Industrial Development'. At inter-company level, 'Industrial Ecology', a subset of Eco-Industrial Development, uses natural ecosystems as metaphors to design sustainable industrial systems [15]. Industrial Ecology aims to transform traditional linear industrial ecosystems into cyclic, or quasi cyclic, ecosystems (where the output of a process becomes the input of another one). This instrument of Industrial Ecology is called 'Industrial Symbiosis'.

An Eco-Industrial Park (EIP) is a type of industrial or business park implementing a long term Industrial Ecology strategy through, among other initiatives, Industrial Symbiosis. The most famous definition of an EIP was proposed by the U.S. President's Council on Sustainable Development in the mid-1990s : " a community of businesses that cooperate with each other and with the local community to efficiently share resources (information, materials, energy, infrastructure and natural habitat), leading to economic gains, improvements in environmental quality and equitable enhancement of human resources for businesses and the local community" [25]. An extensive body of literature is available on the study of EIPs and, more generally, Industrial Ecology. A number of authors highlight the lack of a robust framework to evaluate the performance and benefits of an EIP and to support its sustainable development $[7,24,26]$. Indeed, it is a rather complex task to monitor an EIP's performance over time. A multi-disciplinary and international community has been working on this topic over the last decades. As a way to contribute to this topic, we suggest the use of endorsed industrial practices and tools. 
In parallel, since the 1980s, a lot of work has been done in the field of Supply Chain Management (SCM). The Supply Chain (SC) is also an inter-company organisation model that integrates increasingly sustainable development purposes. It is defined as the life cycle processes comprising physical, information, financial and knowledge flows whose purpose is to satisfy end-user requirements with products and services from multiples liked supplies [3]. Managing the Supply Chain leads to various contributions in terms of its design, scheduling, planning, performance evaluation, and operation of its processes for the satisfaction of the final customers [27].

As we can see from their definitions and management objectives, EIPs and SCs present some similarities: they are both communities where businesses collaborate to reach a common goal. Both definitions introduce the notions of physical and information exchanges: shared resources for an EIP and flows for a SC. Among its various goals, SCM aims to measure and improve the performance of the global SC, objectives that are also shared by EIP management. From these observations, the use of SCM tools for EIP management is proposed.

The objective of this prospective article tackles the first step of EIP management which is the description of its resource sharing with a SCM tool that addresses inter-company flows modelling, namely the SCOR model. This work is encompassed in a much larger task: the implementation of a performance evaluation framework for the management and development of EIPs.

This article is structured as follows. First, we introduce preliminary concepts supporting this article, showing links between EIP and SC. Then we present the use of the SCOR model as a management framework for EIPs through a case study on one of the most famous EIPs: Kalundborg in Denmark. Finally, we finish this article with concluding remarks and directions for future work.

\section{Positionning of Eco-Industrial Parks and Supply Chains}

\subsection{Eco-Industrial Park as an application of Industrial Ecology}

The Eco-Industrial Park (EIP) paradigm relies on a very rational and intuitive idea: Industrial Ecology. Industrial Ecology, introduced by Frosch and Gallopoulos in 1989 [15], is a systemic approach that studies materials and energy flows. Jelinski proposed three development models for Industrial Ecology, starting from the linear and immature ecosystem (Type I) that is unsustainable to the semi-matured ecosystem (Type II) through to a mature materially closed ecosystem that is ultimately sustainable (Type III) [18,1]. These three development models are illustrated in Figure 1. As we mentioned before, Industrial Ecology means to transform traditional type I industrial systems into type III, or at least type II, systems [21]. This concept, also called 'Industrial Symbiosis' uses natural ecosystems as analogies to design sustainable industrial systems.

A large body of symbioses has been documented and studied, such as Kalundborg EIP (further described in section 4); the Austrian province of Styria; the Jyväskylä region in Finland [19]; the petrochemical complex of Sarnia [10]; and the Burnside Cleaner Production Centre in Canada [8]. These prosperous symbioses, and other varyingly successful attempts to realize Industrial Ecology, resulted in different criteria defining an Eco-Industrial Development. Chertow [6] proposed the following taxonomy of different material exchange types:

Material exchanges taxonomy from Chertow [6]:

- Type 1 : through waste exchanges

- Type 2 : within a facility, firm, or organizations

- Type 3 : among firms co-located in a defined eco-industrial park

- Type 4 : among local firms that are not co-located

- Type 5 : among firms organized "virtually" across a broader region

Types 3-5 offer approaches that can readily be identified as industrial symbioses and this paper will be restricted to EIP, precisely corresponding to Type 3 . The symbiosis in an EIP is built around two main types of collaborations : substitution synergies (bilateral materials or energy exchanges) and mutualisation synergies (pooling of resources between two or more companies)

Recent work on the concept of EIP deals with the evaluation of its performance through the definition of new indices $[23,26]$ and the use of multi-criteria decision making approaches [30,29]. Researchers in Industrial Ecology are increasingly moving away from the natural ecosystem metaphor towards more complex, dynamic and systemic approaches [11,14]. Indeed, the design of industrial symbiosis was investigated through optimisation methods [5], the use of system engineering [16] or the use of agent-based modelling [9]. 


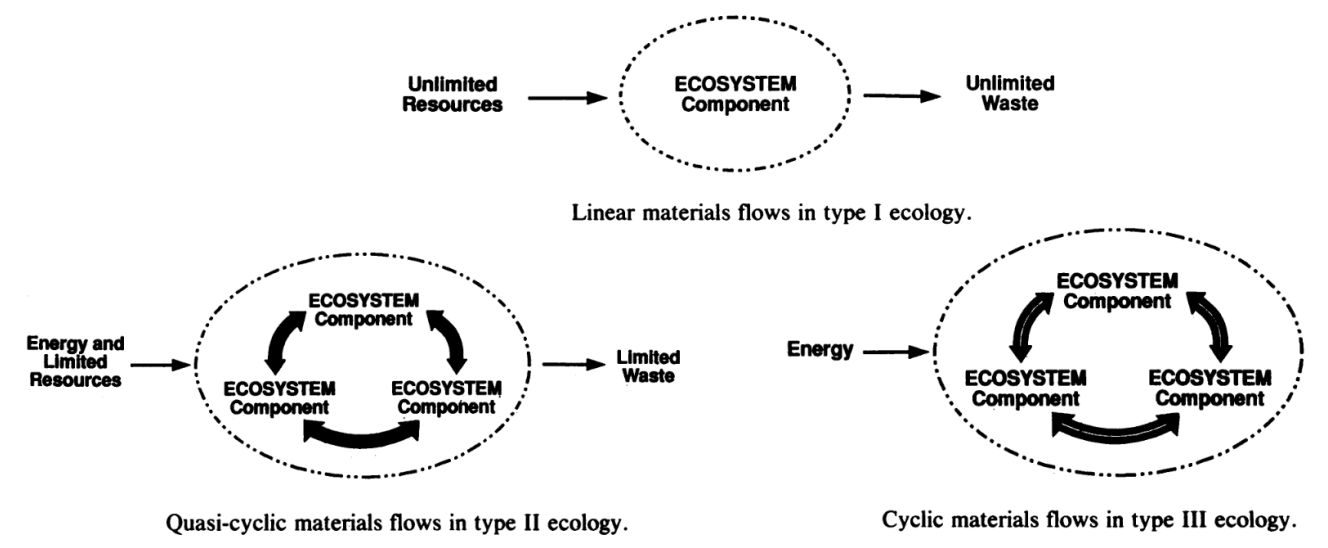

Fig. 1. The three types of ecology, from linear to cyclic industrial systems [18]

\subsection{Supply Chains and Supply Chain management}

The network of relationships between companies from the first supplier to the final customer is called Supply-Chain (SC). As we have mentioned before and according to Huan et al. [17], SCM research can be classified into three categories : Operational, Design and Strategic. Operational SCM is concerned with the daily operations along the main functions of the SC; Design SCM focuses on the location of decision spots along the SC and the achievement of the objectives of the chain; and Strategic SCM intends to understand the dynamics of a supply chain and development of objectives for the whole chain in order to help decision-makers in the evaluation of alternative SC configurations and partnerships. The SCOR model has emerged as a standard tool in Strategic SCM.

Another area in SCM that is close to EIP management and that has gained a lot of interest in the last two decades is Green SCM. Green SCM aims to minimise or eliminate wastages including hasardous chemical, emissions, energy and solid waste along SC [22,2,13].

\subsection{EIP and Supply Chain}

From the definitions in section 2.1 and 2.2, we observe that EIPs and SCs show some similarities. The parallel between SC and Eco-Industrial Parks has been exploited by Zhu and Cote with their study of the evolution of the Guitang Group, a Chinese sugar complex, towards an eco-industrial development by applying integrated Green SCM [31]. Li et al support the idea that green SC should be built inside EIP to create a "green economy" [20].

We propose a non-exhaustive comparison of both concepts in order to demonstrate the pertinence of using SCM tools for EIP's symbiosis management. We inventoried the differences and similarities in Table 1.

SCs and EIPs were created around different philosophies and motivations. SCs are focused on the production of a common product and the satisfaction of a final customer. Their management goal is to improve quality, productivity and security. Members of an EIP do not collaborate for the production of a product but for the reduction in costs and environmental impacts, and the improvement of their employees' work conditions.

The outcome we draw from this comparison is that there are no real arguments against the use of SCM tools to model the industrial symbiosis of an EIP. A SCM tool that addresses inter-company collaboration modelling is the SCOR-model, hence we proposed the use of the SCOR-model for the description of EIPs' flows.

\section{Supply Chain management applied to EIP}

\subsection{Presentation of the SCOR model}

The Supply-Chain Operations Reference-model (SCOR) is a cross-industry standard for SC management developed by the Supply-Chain Council (SCC). It is a diagnostic tool for practitioners describing the processes of a SC from the first supplier company to the last customer company. SCOR model integrates the well-known concepts of business process re-engineering, benchmarking, and process measurement into a framework which includes [17]: 
Table 1. Comparison between an EIP and a SC

\section{Similarities}

Both are groups of companies

Companies involved are production companies (of goods or services)

Both concepts are based around the organisation of a collaboration between the involved companies

All involved companies are working towards a common goal (but their goals are different)

Exchanges of flows exist in both organisations (physical or information)

The exchanges are based on long term deals (several years in most cases)

Both concepts show a strong interest in logistics issues

Differences

$\mathrm{SC} \quad$ EIP

If the SC don't involve a vertically integrated firm, An EIP can be organised around a focal company it will be organised around a focal company, the but it will likely be managed by an external observer primer manufacturer

Well defined roles for each company

Each company's role depends on the chosen perspective

The output of a SC is focused on common products The output of EIP is the collection of each member's products

Geographical proximity is not mandatory All the companies are co-located in a defined area.

1. standard descriptions of management processes;

2. a framework of relationships among the standard processes;

3. standard metrics to measure process performance;

4. management practices that produce best in class performance;

5. standard alignment to software features and functionality

As we can see in Figure 2, in the most recent version of the SCOR model, the processes are of six types :

1. Plan describes the activities associated with developing plans to operate the supply chain

2. Source describes the ordering (or scheduling of deliveries) and receipt of goods and services.

3. Make describes the activities associated with the conversion of materials or creation of the content for services.

4. Deliver describes the activities associated with the creation, maintenance and fulfilment of customer orders

5. Return describes the activities associated with the reverse flow of goods.

6. Enable describes the associated with the management of the supply chain.

The processes can be approached at four levels of abstraction, from the most generic (level 1) to the most particular (level 4). Level 1, or 'Top Level', defines the scope and content for the SCORmodel (performance targets). At level 2, or 'Configuration level' , companies implement their operations strategy through the configuration they choose for their SC. At level 3, or 'Process Element level', companies 'fine tune' their operations through process elements definition, process performance metrics and advice on the best practices. The last level, called 'Implementation level' is not included in SCOR's scope.

As SCOR model provides this well equipped cross-functional framework, we believe that it would be beneficial to use it for the evaluation, benchmarking and decision making for the development of an EIP.

\subsection{The SCOR model transferred to the EIP}

The interactions between two members of an EIP can be of two different types : a bilateral exchange called substitution synergy or a pooling of resources called mutualisation synergy.

Substitution synergy A substitution synergy is a bilateral exchange of energy or materials. Using SCOR's process structure, a substitution synergy is the link between the Source process of a company and the Deliver process of another. Since one of EIPs' goals is to optimise their inputs in a circular way, a material exchange could be of various ancillary products. The materials emitted by a company can be of four types [31]: 


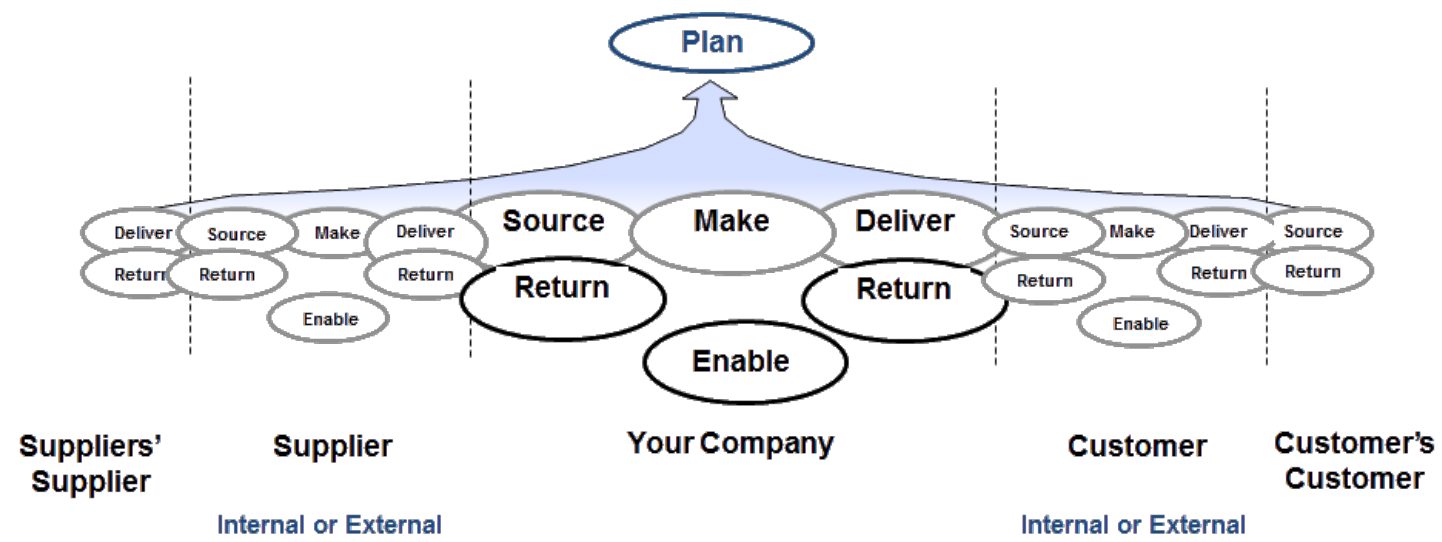

Fig. 2. The SCOR overall Supply Chain processes structure (APICS, SCOR 11.0 Overiew Booklet, 2014)

1. Products, the desired output of the process;

2. Co-products, which represent substantial value even if they are not the intended product of the process;

3. By-products, unintentionally produced, that represent a lesser, but positive, value than the original raw material;

4. Residual products, or waste, with a negative value.

For example, a sugar refinery's product is sugar, two co-products are molasses and bagasse, and a residual product is filter sludge. The bagasse can be used in a pulp plant. The emissions of the pulp plant are the pulp (product), black liquor (by-product), and waste-water (residual product).

Because of these different types of materials, the Deliver process can sometimes be coupled to an ancillary Make and Deliver processes (Make' and Deliver') to either tailor them for their next use (co-products and by-products) or to treat them to respect regulations (by-products and residual products). Therefore, we propose to represent the members of an EIP as shown in Figure 3. Because substitution synergies are focused on materials, we ignore the processes Plan and Enable. Moreover, for this first modelling, we neglect the Return process.

Mutualisation synergy Using SCOR's process structure, a mutualisation synergy is the pooling processes between two, or more, companies. In theory, all the processes can be shared, but in practice, the most common pooling will likely be the Deliver and Source process. For example, two, or more, companies can come to an agreement to be delivered by the same carrier at the same time to minimise the shipping cost and environmental impact. In a similar fashion, the carrier importing materials in the EIP can be used to export finished products outside the EIP. With a bit more planning, the Return process can be organised in a collaborative way. Companies can share resources used in the Make process, such as quality control or information systems. A very common collaboration inside a EIP will be residual product treatment at the Make' process.

\section{Case Study}

\subsection{Some elements about Kalundborg EIP}

The most famous and documented industrial symbiosis is located in Kalundborg in the Denmark [12]. Kalundborg's industrial symbiosis was built spontaneously, its development was progressive and with no planning. Since 1972, more than thirty materials or energy exchanges were established between the members of the symbiosis : six processing companies, a waste handling company and the municipality of Kalundborg. These bilateral agreements allowed to avoid production of waste and saved a consequential amount of resources. Only seeking economic profit, the members also reaped non-negligible environmental benefits and, following on from this success, Kalundborg has become the exemplary model for Eco-Industrial Development. 


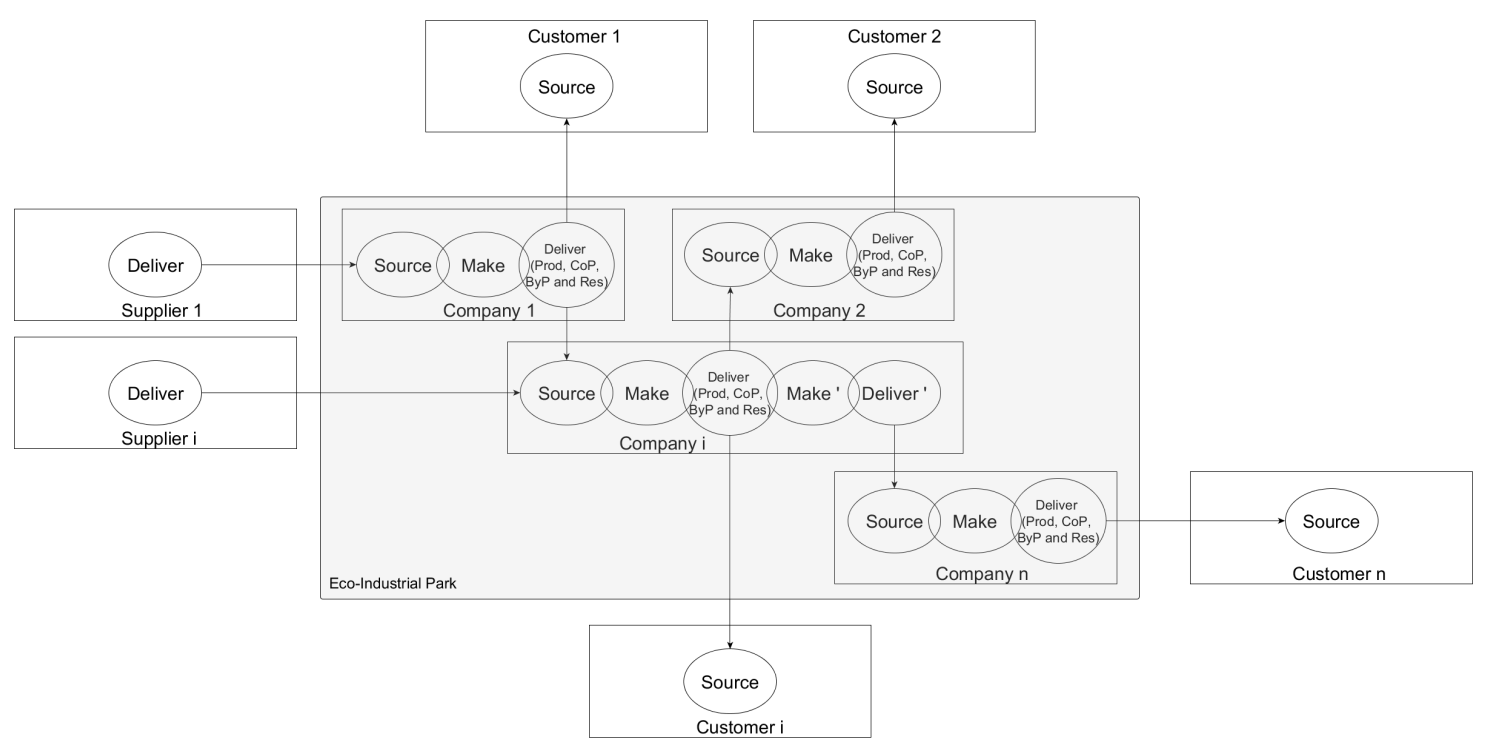

Fig. 3. Processes structure of an EIP of $\mathrm{n}$ companies inherited from the SCOR model (Prod=Product, CoP $=$ Co-Product, ByP=By-Product and Res=Residual Product)

\subsection{Application of the SCOR-inherited model to Kalundborg EIP's symbiosis}

As an example of the application of the SCOR model to an EIP, we chose to represent Kalundborg Symbiosis with the process structure described in paragraph 3.2. Information on Kalundborg's EIP were provided by Kalundborg's symbiosis official website ${ }^{4}$ to obtain the most up-to-date data. Indeed, Kalundborg's symbiosis is dynamic: new substitution synergies are sometimes created or broken. With the data gathered, we mapped Kalundborg's symbiosis, as can be seen in Figure 4. Except for Lake Tisso's surface water, we chose to only represent co-product, by-product and residual product flows within the EIP and their recovery outside the EIP. For the sake of clarity, the EIP members' products and imported primary materials are excluded of the figure and we differentiated energy, water and materials flows. The members of Kalundborg's EIP are :

1. Novo Nordisk, the world's largest producer of insulin;

2. Novozymes, the world's largest producer of enzymes;

3. Gyproc, producer of gypsum board;

4. Kalundborg Municipality, which handles the water and heat supply for Kalundborg's 50,000 inhabitants;

5. Dong Energy, owner of the Asnæs Plant, the biggest coal fuelled power plant in Denmark;

6. Statoil, owner of Denmark's biggest oil refinery;

7. Kara/Novoren, a small waste treatment company;

As we can see in Figure 4, DONG Energy and Novozymes both have ancillary Make' and Deliver' processes. Besides Asnæs Plant, DONG Energy owns Inbicon, a world leading lignocellulosic biomass conversion technology that uses Asnæs Plant surplus steam. Novozymes also owns a waste water treatment facility that uses Novozymes' biomass and Novo Nordisk's ethanol waste to produce NovoGro 30, used as a fertilzer by the farms nearby. Finally, since Kalundborg EIP is not focused on mutualisation synergies, our SCOR-inherited model only offers a mapping of the substitution synergy network.

The SCOR model is shown to be a standard enabling the mapping of EIP symbiosis. This first work addressed the use of the SCOR model as a descriptive model, but the SCOR framework offers other services such as benchmarking and performance metrics. Knowing that the SCOR can be adapted to describe an EIP is a first promising step towards the use of all its utilities. Since the philosophy and the goals of an EIP and a SC are not similar, additional work should be done to tailor the SCOR model for the performance evaluation of an EIP.

\footnotetext{
${ }^{4}$ http://www.symbiosis.dk/en/diagram
} 


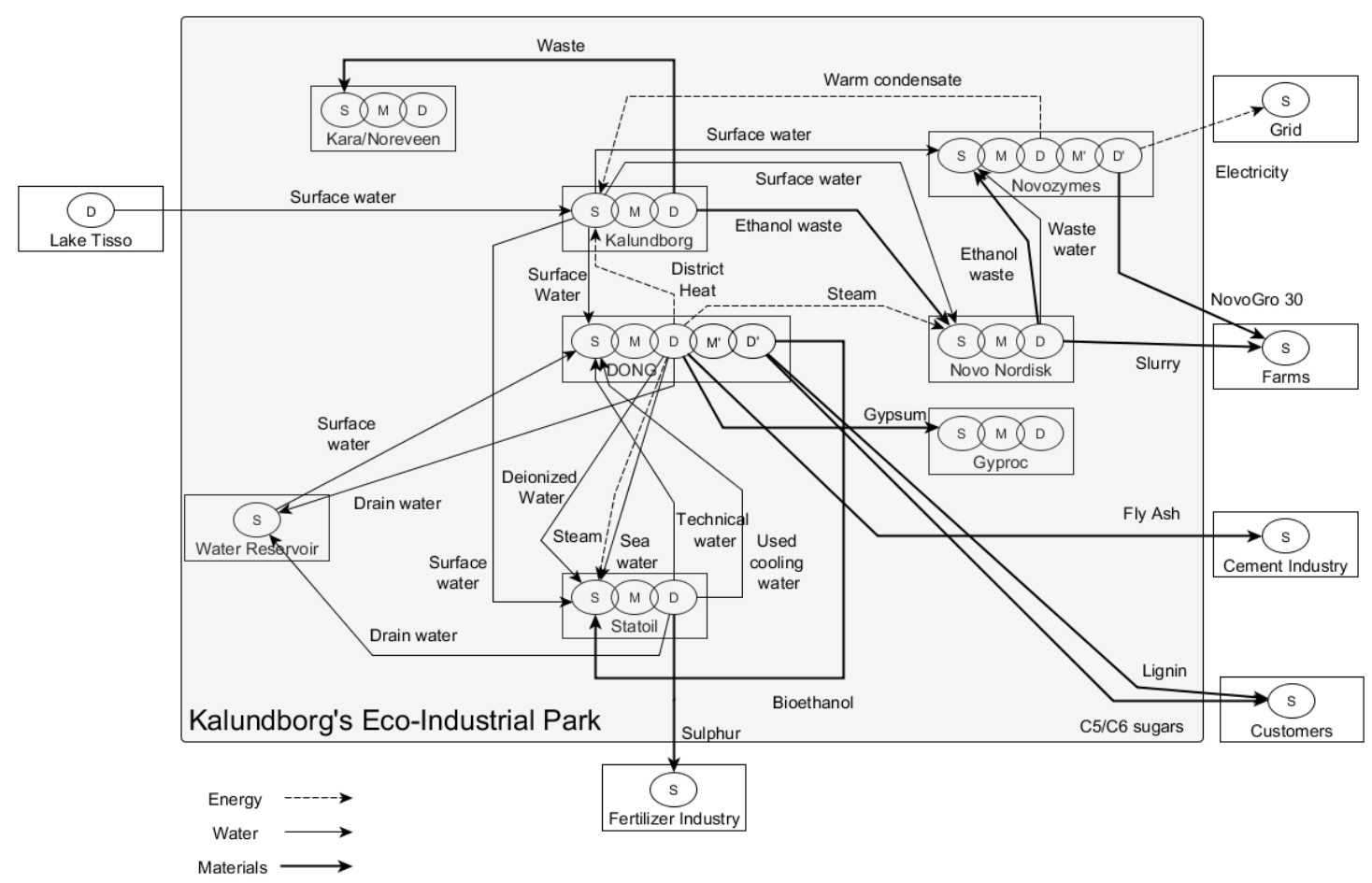

Fig. 4. Kalundborg symbiosis represented with the inherited SCOR process structure

\section{Conclusion}

Owing to growing environmental concerns, the concept of Industrial Ecology has gained a lot of attention through its concrete application : EIPs. Observing some similarities between EIPs and SCs, we proposed the use of a SCM tool to describe an EIP's symbiosis. The SCOR-model, is Strategic SCM tool helping with the description and performance evaluation of the processes along the SC, was adapted to map the substitution synergies among an EIP. Applying our SCORinherited model to Kalundborg EIP, we have shown that it offers a standardised and original way to represent the processes inside an EIP. In the near future, we wish to apply our SCOR-inherited model to other EIPs: Savoie Technolac, a French Technopole with a philosophy close to the EIP's; Pomacle-Bazancourt EIP in France, one of the most successful example of bio-refinery in Europe; and the developing EIP of Victoriaville in Quebec

This prospective work introduces the possibility to use the SCOR model at its fullest, for the evaluation, benchmarking and decision making for the development of an EIP. It also allows the use of other SCM tools associated with the SCOR-model such as performance measurement systems, multi-criteria decision making tools, and aggregation operator, such as the Choquet Integral [4]. Finally, this work means to inspire further research using tools endorsed in the industrial sector for the management and performance measurement of EIPs.

\section{References}

1. Agarwal, A., Strachan, P.: Literature review on eco-industrial development initiatives around the world and the methods employed to evaluate their performance/effectiveness. The Robert Gordon University (June) (2006)

2. Ahi, P., Searcy, C.: A comparative literature analysis of definitions for green and sustainable supply chain management. Journal of Cleaner Production 52, 329-341 (2013)

3. Ayers, J.B.: Handbook On Supply Chain Management (2001)

4. Berrah, L., Clivillé, V.: Towards an aggregation performance measurement system model in a supply chain context. Computers in Industry 58(7), 709-719 (2007)

5. Boix, M., Montastruc, L., Azzaro-Pantel, C., Domenech, S.: Optimization methods applied to the design of eco-industrial parks: A literature review. Journal of Cleaner Production 87(1), 303-317 (2015)

6. Chertow, M.R.: Industrial symbiosis: Literature and taxonomy. ANNUAL REVIEW OF ENERGY AND THE ENVIRONMENT 25, 313-337 (2000) 
7. Chertow, M.R.: Evaluating the success of eco-industrial development. In: Eco-industrial Strategies: Unleashing Synergy between Economic Development and the Environment, pp. 258-268 (11) (2003)

8. Côté, R., Booth, A., Louis, B.: Eco-efficiency and SMEs in Nova Scotia, Canada (2006)

9. Couto Mantese, G., Capaldo Amaral, D.: Comparison of industrial symbiosis indicators through agentbased modeling. Journal of Cleaner Production 140, 1652-1671 (2017)

10. Desrochers, P.: Cities and Industrial Symbiosis: Some Historical Perspectives and Policy Implications. Journal of Industrial Ecology 5(4), 29-44 (2001), http://www3.interscience.wiley.com/journal/ 120135452/abstract $\{\%\} 255$ Cnhttp://doi.wiley.com/10.1162/10881980160084024

11. Dijkema, G.P.J., Basson, L.: Complexity and Industrial Ecology. (2009), http://10.0.4.87/j . 1530-9290.2009.00124.x\{\%\}255Cnhttps://login.e.bibl.liu.se/login?url=https://search. ebscohost. com/login. aspx?direct $=\operatorname{true}\{\&\} \mathrm{db}=\operatorname{aph}\{\&\} \mathrm{AN}=37815157\{\&\}$ site $=$ eds -1 ive $\{\&\}$ scope $=$ site

12. Ehrenfeld, J., Gertler, N.: Industrial Ecology in Practice: The Evolution of Interdependence at Kalundborg. Journal of Industrial Ecology 1(1), 67-79 (1997), http://doi.wiley.com/10.1162/jiec.1997. 1.1 .67

13. Fahimnia, B., Sarkis, J., Davarzani, H.: Green supply chain management: A review and bibliometric analysis (2015)

14. Felicio, M., Amaral, D., Esposto, K., Gabarrell Durany, X.: Industrial symbiosis indicators to manage eco-industrial parks as dynamic systems. Journal of Cleaner Production 118, 54-64 (2016)

15. Frosch, R.A., Gallopoulos, N.E.: Strategies for Manufacturing Waste from one industrial process can serve as the raw materials for another, thereby reducing the impact of industry on the environment. Scientific American Ou Scientific American 189(2613), 144-152 (1989)

16. Haskins, C.: A systems engineering framework for eco-industrial park formation. Systems Engineering 10(1), 83-97 (2007)

17. Huan, S.H., Sheoran, S.U.K., Wang, G.: A review and analysis of supply chain operations reference (SCOR) model. Supply Chain Management 9(1), 23 (2004), http://proquest . umi. com/pqdweb?did= $612621331\{\&\} \mathrm{Fmt}=7\{\&\} \mathrm{client} I d=20931\{\&\} \mathrm{RQT}=309\{\&\}$ VName=PQD

18. Jelinski, L.W., Graedel, T.E., Laudise, R.a., McCall, D.W., Patel, C.K.: Industrial ecology: concepts and approaches. Proceedings of the National Academy of Sciences 89(3), 793-797 (1992), http://www . pnas.org/cgi/doi/10.1073/pnas.89.3.793

19. Korhonen, J., Wihersaari, M.: Industrial Ecology of a Regional Energy Supply System. Greener Management International (26), 57 (1999), http://search.ebscohost.com/login. aspx?direct=true $\{\&\}$ db $=b \operatorname{th}\{\&\}$ AN $=2742659\{\&\}$ site $=$ ehost $-l i v e\{\%\} 255 \mathrm{Cnhttp}: / /$ content . ebscohost . com/ContentServer $\cdot$ asp? $\mathrm{T}=\mathrm{P}\{\&\} \mathrm{P}=\mathrm{AN}\{\&\} \mathrm{K}=2742659\{\&\} \mathrm{S}=\mathrm{R}\{\&\} \mathrm{D}=\mathrm{bth}\{\&\}$ EbscoContent $=$ dG JyMMTo50SeqK84xNvg0LCmr0yep65Sr6m4SrGWxWXS \{\&\}ContentCustomer=dGJyMPGut0i3ra9Ju

20. Li, J., Pan, S.Y., Kim, H., Linn, J.H., Chiang, P.C.: Building green supply chains in eco-industrial parks towards a green economy: Barriers and strategies. Journal of Environmental Management 162, $158-170(2015)$

21. Lowe, E.A.: Creating by-product resource exchanges: Strategies for eco-industrial parks. Journal of Cleaner Production 5(1), 57-65 (1997)

22. Srivastava, S.K.: Green supply-chain management: A state-of-the-art literature review. International Journal of Management Reviews 9(1), 53-80 (2007)

23. Tiejun, D.: Two quantitative indices for the planning and evaluation of eco-industrial parks. Resources, Conservation and Recycling 54(7), 442-448 (2010)

24. Tudor, T., Adam, E., Bates, M.: Drivers and limitations for the successful development and functioning of EIPs (eco-industrial parks): A literature review. Ecological Economics 61(2-3), 199-207 (2007)

25. U.S President Council on Sustainable Development: Eco-industrial park workshop proceedings. Tech. rep., Washington, DC (1997)

26. Valenzuela-Venegas, G., Salgado, J.C., Diaz-Alvarado, F.A.: Sustainability indicators for the assessment of eco-industrial parks: classification and criteria for selection (2016)

27. Villa, A.: Introducing some supply chain management problems. International Journal of Production Economics 73(1), 1-4 (2001), http://www.scopus.com/inward/record.url?eid=2-s2. $0-0035979647\{\&\}$ partnerID $=40\{\&\} \mathrm{md} 5=7 \mathrm{~d} 15 \mathrm{af}$ e28d236d3586747941 feed5e 5

28. World Commission On Environment And Development: Our Common Future. Tech. rep. (1987), http: //www.un-documents.net/wced-ocf.htm

29. Zhao, H., Zhao, H., Guo, S.: Evaluating the comprehensive benefit of eco-industrial parks by employing multi-criteria decision making approach for circular economy. Journal of Cleaner Production (2016), http://linkinghub.elsevier.com/retrieve/pii/S0959652616318807

30. Zhao, H., Li, N.: Evaluating the performance of thermal power enterprises using sustainability balanced scorecard, fuzzy Delphic and hybrid multi-criteria decision making approaches for sustainability. Journal of Cleaner Production 108, 569-582 (2015)

31. Zhu, Q., Cote, R.P.: Integrating green supply chain management into an embryonic eco-industrial development: A case study of the Guitang Group. Journal of Cleaner Production 12(8-10), 1025-1035 (2004) 